\title{
Delayed Pulmonary Embolism after Mild COVID-19: A Case Report
}

\section{Hafif COVID-19 Sonrası Gecikmiş Pulmoner Emboli: Olgu Sunumu}

Fatma Tokgöz Akyıl, Seda Tural Önür, Kübra Gül Kılınçarslan, Kaan Kara, Mustafa Vedat Dogru, Nurdan Şimşek Veske, Melih Akay Arslan

\begin{abstract}
COVID-19 coagulopathy has gained attention due to the strikingly high prevalence of deep vein thrombosis (DVT) and pulmonary embolism (PE). We describe here a case of bilateral PE preceded by mild COVID19 contracted 4.5 months earlier in a male patient who presented to the outpatient clinic with exertional dyspnea. The patient had developed PE 9 years earlier, when no underlying genetic factor was detected. In the 4.5 months after contracting mild COVID-19, he presented four times with exertional dyspnea and a thorax computer tomography angiography (CTA) on two occasions and one perfusion scintigraphy revealed no embolism. Based on his high D-dimer values, his symptoms and his history of PE, he was placed on prolonged PE prophylaxis, which was stopped 33 days ago, and at that time, CTA revealed extensive bilateral PE. In conclusion, an unusually longer activation in COVID-19 coagulopathy may co-exist in patients with a history of previous PE, ongoing symptoms and increased D-dimer levels, irrespective of the COVID-19 severity.
\end{abstract}

Key words: Pulmonary embolism, thrombosis, SARS-CoV-2.

\begin{abstract}
Özet
Yeni koronavirüs hastalığı (COVID-19) derin ven trombozu (DVT) ve pulmoner emboli (PE) sıklığında artış ile ilişkilendirilen koagülopati ile dikkat çekmiştir. Bu olgu sunumunda hafif COVID-19 sonrası saptanan bilateral yaygın PE olgusu tartışılmıştır. Elli yedi yaşında, eforla artan nefes darlığı şikayetiyle polikliniğimize başvurdu. Dokuz yıl önce PE geçirmiş, genetik bir risk faktörü saptanmamışı. Dört buçuk ay önce COVID-19 tanısı konulmuş, hafif semptomlar ile düzelmişti. Daha sonra dört kez efor dispnesi nedeniyle polikliniğimize başvurmuş, diğer nedenler dışlanmış, yüksek d-dimer düzeyleri nedeniyle çekilen iki toraks bilgisayarlı tomografi anjiyografi (BTA) ve perfüzyon sintigrafisinde emboli saptanmamıştı. Uzun süre devam edilen PE profilaktik tedavisi 33 gün önce kesilmişti. D-dimer düzeyinde artış nedeniyle yeniden BTA çekilen hastada bilateral ana pulmoner arterlerde trombüs saptandı. Sonuç olarak, hafif COVID-19 hastalığı geçiren hastalarda dahi, devam eden semptomlar, yüksek D-dimer düzeyleri ve daha önceki PE öyküsü; daha uzun süren COVID-19 koagülopatisi için uyarıcı olabilir.
\end{abstract}

Anahtar Sözcükler: Pulmoner emboli, trombozis, COVID- 19.
Yedikule Chest Diseases and Thoracic Surgery Training and Research Hospital, İstanbul, Turkey
Yedikule Göğüs Hastalıkları ve Göğüs Cerrahisi Eğitim ve Araştırma Hastanesi, İstanbul

Submitted (Başvuru tarihi): 05.08.2021 Accepted (Kabul tarihi): 06.09.2021

Correspondence (iletișim): Fatma Tokgöz Akyıl, Yedikule Chest Diseases and Thoracic Surgery Training and Research Hospital, İstanbul, Turkey

e-mail: fatmatokgoz86@gmail.com 
The novel coronavirus pandemic has seen over 172 million infections and over 3.7 million deaths worldwide (1). Aside from the initial stages of infection, comorbidities and post-viral complications have yielded a high rate of morbidity and mortality.

Clinical studies have identified an increased risk of venous thromboembolism (VTE) in COVID-19 patients. The viral infection activates proinflammatory cytokines, platelets and leucocytes, leading eventually to endothelial injury. Increased Von Willebrand factor (vWF), FXII and neutrophil extracellular traps predispose to the generation of thrombin, fibrin deposits and the formation of thrombus. The mechanisms resulting in deep vein thrombosis (DVT), pulmonary embolism (PE) and other coagulopathies are referred to collectively as "COVID-19 coagulopathy" $(1,2)$.

The incidence of VTE is $5-10 \%$ in hospitalized patients and $30 \%$ in patients requiring treatment in the intensive care unit (ICU). The estimated prevalence of PE, as the most common manifestation of VTE, is $4-23 \%$ (3). Anticoagulation therapy is the optimum approach to the prevention and treatment of thromboembolic disease (4). Heparin - in both its unfractionated (UFH) and low molecular weight $(\mathrm{LMWH})$ forms - is shown to improve the prognosis of COVID-19 patients and lower the 28-day mortality in patients meeting SIC criteria or with elevated D-dimer (5).

It is not clear whether preventive anticoagulation treatments should be continued after discharge. An estimated rate of $2.5-5 \%$ VTE is suggested in post-discharge patients (6). Prolonged VTE prophylaxis is suggested only in post-discharge patients in the presence of certain risk factors, which include impaired mobilization, active malignancy, higher VTE risk scores, advanced age, more than twice the normal D-dimer values and previous history of VTE $(1,7)$. Only a limited number of clinical studies have focused on VTE in post-acute COVID-19. A prospective study evaluating the incidence of post-discharge VTE with D-dimer levels and venous ultrasound found that one out of 102 patients developed asymptomatic VTE, and only $8 \%$ received post-discharge thromboprophylaxis in this cohort (8). No prolonged prophylaxis is recommended for mild COVID-19 patients, although cases have been reported where VTE was detected even 3 months after PCR positivity $(9,10)$.

We report here on a patient with bilateral and extensive $P E$, detected 4.5 months after contracting mild COVID19. The patient is discussed in terms of his 9-year history of $P E$, his frequent admission with ongoing symptoms and his diagnostic work-up in the outpatient clinic.

\section{CASE}

A 57-year-old male presented to the outpatient clinic with complaints of gradually decreased exercise tolerance and mild chest pain. He had been diagnosed with diabetes mellitus and chronic obstructive pulmonary disease 5 years earlier and had been followed-up regularly. He had developed PE 9 years earlier, but with no genetic predisposing factor. His weight was $120 \mathrm{~kg}$, height $1.88 \mathrm{~m}$ and was a former swimmer who still exercised regularly.

The patient had been diagnosed with COVID-19 pneumonia based on a real-time polymerase chain reaction (PCR) test 4.5 months earlier, and had been treated at home (Figure la and b). He had presented previously to our COVID outpatient clinic on four previous occasions with exertional dyspnea and occasional chest pain. During all visits, respiratory tract infection, COPD exacerbation, respiratory failure and cardiac pathology were excluded.
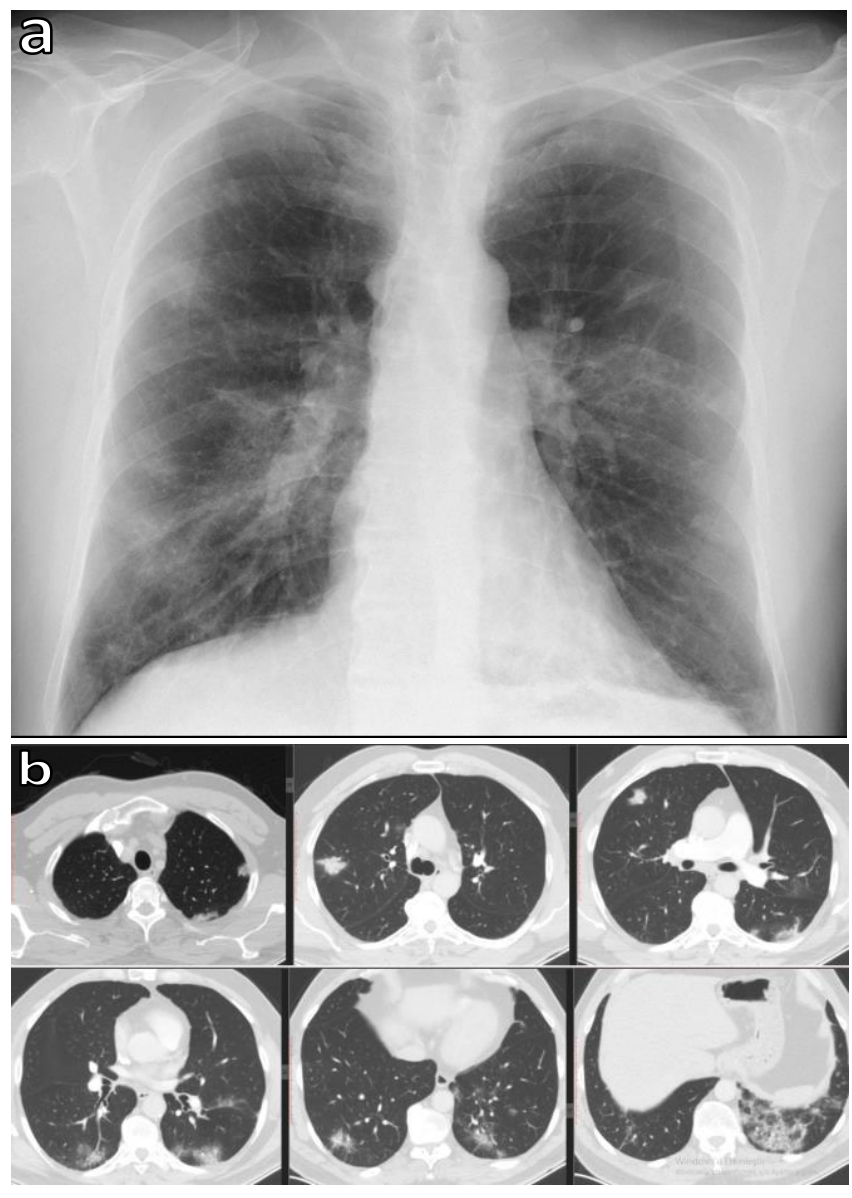

Figure la and b: Chest $X$-ray and Thorax CT at COVID diagnosis (PCR positive) 
On day 40 , a follow-up examination revealed radiological regression and the patient complained of mild exertional dyspnea (Figure 2). Due to the PE history and increased D-dimer values, prophylactic enoxaparin therapy was prolonged.

In week 8 the patient underwent a thorax computer tomography angiography (CTA) and no PE was detected (Figure 3), although the anticoagulation was continued due to the patient history and symptoms.

In week 15, perfusion scintigraphy was performed due to the persistence of symptoms to exclude chronic thromboembolism. Perfusions of both lungs up to the segmental and subsegmental levels were normal. The VTE prophylaxis was planned to be discontinued (Figure 4), although it was learned that he had continued with the previouslyprescribed prophylactic enoxaparin treatment for three more weeks.

In his last outpatient clinic admission 33 days ago with similar symptoms, D-dimer was increased $(1.18 \mathrm{mg} / \mathrm{L})$ and CTA did not indicate PE, and anticoagulant therapy was subsequently stopped (Figure 5).

At presentation, his physical examination results and vital signs were normal (respiratory rate: 14/minute, heart beat $92 / \mathrm{min}$, arterial tension: $110 / 70 \mathrm{mmHg}$, oxygen saturation at room air: $94 \%$ ); while laboratory parameters revealed: glucose: 110 (74-109) mg/dl, creatinine: 1.17 (0.6-1.2) mg/dl, blood urea nitrogen: 28 (10-50) mg/dl, CRP: 4 (0-5) mg/L, leucocytes: 8.34 103/uL, hemoglobin: $14.5(11-16) \mathrm{g} / \mathrm{dL}$, platelet: $280(103 / \mathrm{uL})$ and D-dimer $4.61(0-0.5) \mathrm{mg} / \mathrm{L}$.

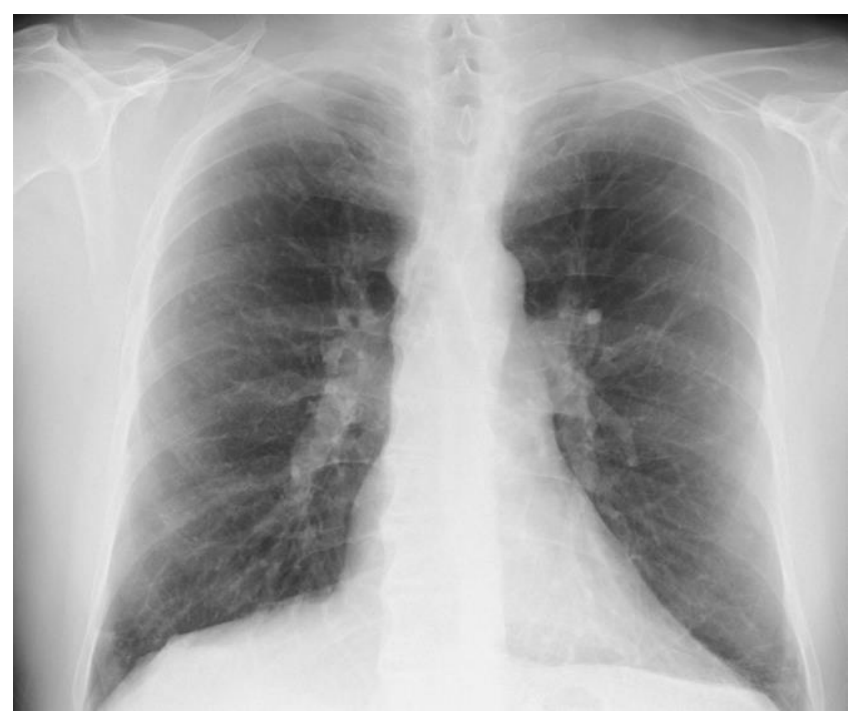

Figure 2: Radiological regression 4 weeks after COVID-19 diagnosis

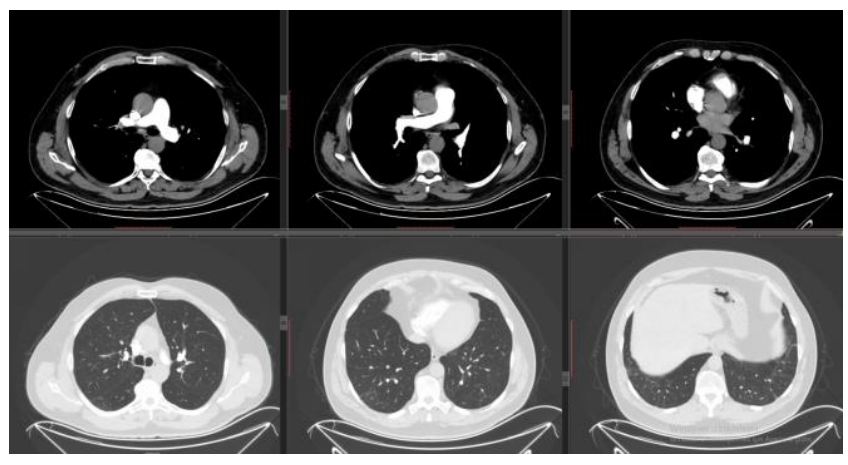

Figure 3: Thorax CT angiography 6 weeks after COVID-19 diagnosis

Due to the increased D-dimer value, CTA was planned, and extensive bilateral PE was detected (Figure 6). The thrombus on the right main pulmonary artery (PA) was lying in the distal segmental and subsegmental branches, and from the left lower lobar PA to the subsegmental branches. A cardiac examination revealed a normal ejection fraction and mild tricuspid insufficiency, while the systolic pulmonary artery pressure was measured at 35 $\mathrm{mmHg}$. The troponin level was $0.018 \mathrm{ng} / \mathrm{ml}$ and the probrain natriuretic peptide (BNP) level was $61 \mathrm{pg} / \mathrm{ml}$. No deep vein thrombosis was detected in a lower limb Doppler ultrasonography.

The patient was placed on half-dose thrombolytic treatment, after which anticoagulant treatment was initiated. At first-month follow-up, the patient was asymptomatic and he informed that he had re-gained his pre-COVID exercise tolerance. Although no genetic risk factor had been detected 9 years earlier, a re-test for genetic risk factors was scheduled.

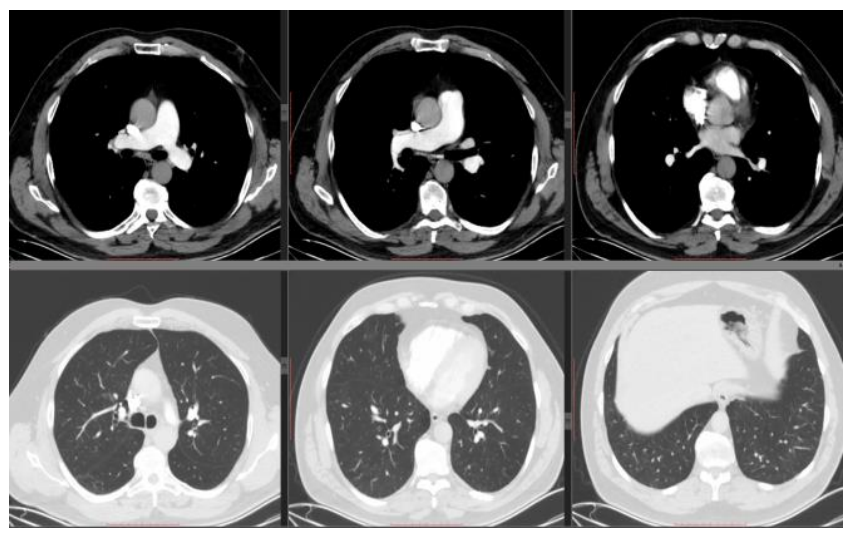

Figure 4: Thorax CT angiography 33 days before PE diagnosis 


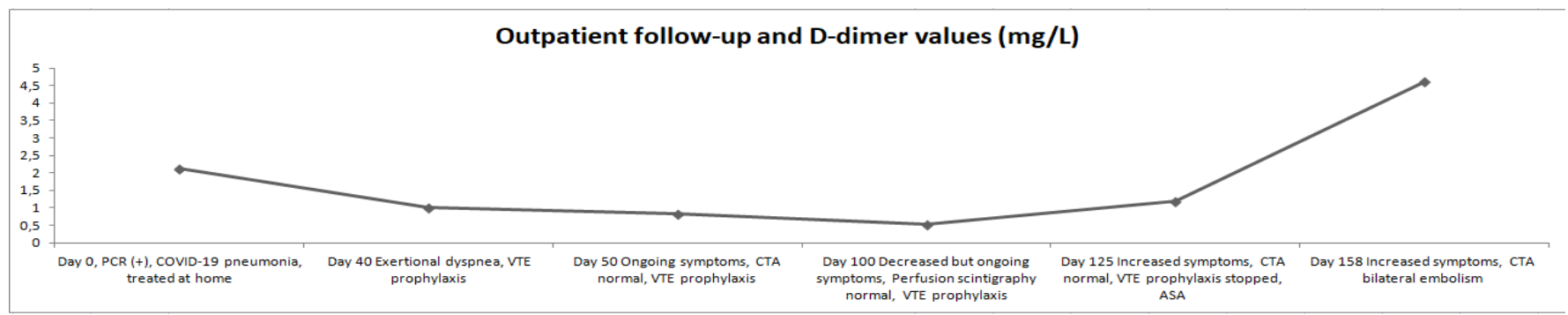

Figure 5: Outpatient follow-up and D-dimer values

\section{DISCUSSION}

The case presented here raises several important points for discussion. Firstly, the patient had only mild COVID19, the resolution of which was verified radiologically. Subsequently, the patient consistently presented to the outpatient clinic with decreased exercise tolerance, which was corroborated by his D-dimer values. With VTE prophylaxis with enoxaparin, the D-dimer values fell gradually, but after discontinuing anticoagulation, his symptoms and D-dimer values re-ascended. The case suggests that an unusually longer COVID- 19 coagulopathy activation may occur due to as-yet unexplained mechanisms in patients with a history of PE. The presence of immune, metabolic, lipid and vascular mechanisms can be defined during infection, although the time until complete recovery and the post-acute phase of vascular injury remains unknown (11). A period of 4 weeks after the onset of symptoms or PCR positivity is defined as acute COVID-19. Persistent symptoms or new complications after 4 weeks and up to 6 months are described as post-acute COVID-19 (12). Venous and arterial thromboembolisms are among the most frequent late complications of COVID-19 (13). Clinical studies have focused mostly on VTE risk in cases of moderate and severe COVID-19 in the post-acute period. Our literature review shows revealed only a limited number of thrombotic complications reported during the later phases. Fan et al. reported four male cases (aged 38-49 years) with delayed acute arterial thrombosis following mild COVID-19. The medical conditions they encountered were middle cerebral artery infarct, pulmonary embolism, infrarenal aortic thrombosis and myocardial infarction in the 41-90 days of COVID-19 infection. Only one patient had diabetes mellitus and the rest had no comorbidities (9). Singh et al. (10) reported nine cases (aged $63 \pm 9$ years, 6 males, and one with co-morbid DM) with acute VTE occurring within an average of 88 days after PCR positivity in which the mean D-dimer value was $6.8 \mathrm{ug} / \mathrm{Ml}$. Of the total, five of the patients were not hospitalized for their COVID-19 treatments, two of which had previous VTE.
The case in the present study had only mild COVID-19, and had been under VTE prophylaxis due to his medical history, ongoing symptoms and high D-dimer values, despite which extensive PE was detected 1 month after treatment was ceased. These findings imply that clinicians should go beyond the general guidelines and remember that when it comes to COVID-19 follow-up and complications, every patient, especially those with underlying medical histories, is a unique case. Our case demonstrates that catastrophic vascular complications may occur up to 6 months after PCR positivity.

The optimum anticoagulation strategies remain unclear. Based on current recommendations, UFH, LMWH and fondaparinux in standard doses are preferred as they have shorter half-lives and fewer interactions with other COVID-19 pharmacological treatments when compared to oral anticoagulants $(1,3,14,15)$. The case presented had undergone 4 months of enoxaparin therapy.

There are currently two main indications for PE prophylaxis in hospitalized COVID-19 patients: i) The decision is made based on specific risk scores, taking respiratory failure, malignancy and heart failure into account; immobilized patients and patients requiring ICU treatment should take prophylaxis if not contraindicated $(1,3)$, ii) All hospitalized patients should take prophylaxis if not contraindicated $(14,15)$. In Turkey, all hospitalized patients are suggested to take a prophylactic dose of heparin (LMWH or UFH). Additionally, patients with a greater than 2-fold D-dimer increase are defined as high-risk for VTE, and are indicated for $>45$ days of prophylactic treatment (16).

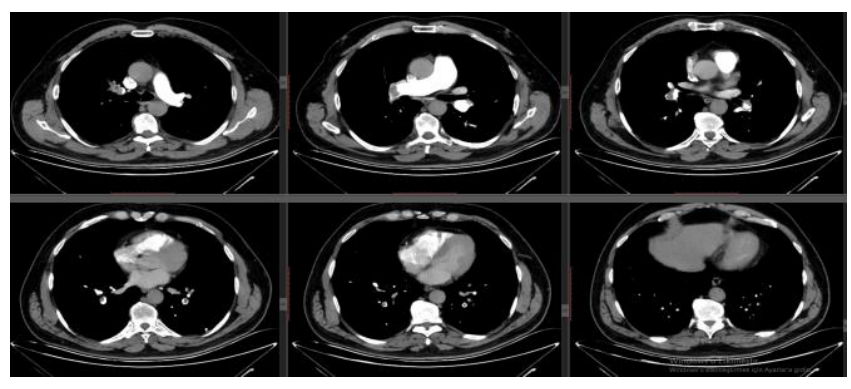

Figure 6: Thorax CT angiography image showing the thrombus on the right main pulmonary artery 
Although daily measurement is not recommended, Ddimer levels can be used as a marker of disease severity and prognosis (6). A retrospective study suggested that baseline D-dimer values higher than $1 \mathrm{mg} / \mathrm{mL}$ are a strong and independent risk factor indication for inhospital mortality (17). Cui et al. (18) identified a Ddimer cut-off value of $1.5 \mathrm{mg} / \mathrm{mL}$ for the detection of VTE, with $85 \%$ sensitivity and $88.5 \%$ specificity. Our case was identified with a sharp D-dimer increase at the time of presentation. Screening and comparisons with previous D-dimer values may point to VTE in these patients.

In conclusion, VTE may be encountered in the long-term after a COVID-19 infection, even in its mild form. A history of embolism, persistent symptoms and an increased trend in D-dimer values should alert clinicians to the possibility of VTE.

\section{CONFLICTS OF INTEREST}

None declared.

\section{AUTHOR CONTRIBUTIONS}

Concept - F.T.A., S.T.Ö, K.G.K., K.K., M.V.D., N.S.V., M.A.A.; Planning and Design - F.T.A., S.T.Ö., K.G.K., K.K., M.V.D., N.S..V., M.A.A.; Supervision - F.T.A., S.T.Ö. K.G.K., K.K., M.V.D., N.Ş.V., M.A.A.; Funding - F.T.A., S.T.Ö.; Materials - F.T.A., S.T.Ö.; Data Collection and/or Processing - F.T.A., K.G.K.; Analysis and/or Interpretation - F.T.A., K.G.K.; Literature Review - F.T.A., K.G.K., S.T.Ö.; Writing - F.T.A., K.G.K., S.T.Ö.; Critical Review - F.T.A., S.T.Ö., K.G.K.

\section{YAZAR KATKILARI}

Fikir - F.T.A., S.T.Ö., K.G.K., K.K., M.V.D., N.Ş.V., M.A.A.; Tasarım ve Dizayn - F.T.A., S.T.Ö., K.G.K., K.K., M.V.D., N.Ş.V., M.A.A.; Denetleme - F.T.A., S.T.Ö., K.G.K., K.K., M.V.D., N.Ş.V., M.A.A.; Kaynaklar - F.T.A., S.T.Ö.; Malzemeler - F.T.A., S.T.Ö.; Veri Toplama ve/veya İşleme - F.T.A., K.G.K.; Analiz ve/veya Yorum F.T.A., K.G.K.; Literatür Taraması - F.T.A., K.G.K., S.T.Ö.; Yazıyı Yazan - F.T.A., K.G.K., S.T.Ö.; Eleştirel İnceleme F.T.A., S.T.Ö., K.G.K.

\section{REFERENCES}

1. Bikdeli B, Madhavan MV, Jimenez D, Chuich T, Dreyfus I, Driggin $E$, et al. COVID-19 and thrombotic or thromboembolic disease: implications for prevention, antithrombotic therapy, and follow-up: JACC state-of-theart review. J Am Coll Cardiol 2020; 75:2950-73. [CrossRef]
2. Sanidas E, Grassos C, Papadopoulos D, Velliou M, Barbetseas J. Pulmonary embolism prophylaxis in patients with COVID-19: an emerging issue. Heart Lung Circ $2021 ; 30: 1435-41$. [CrossRef]

3. Kosior DA, Undas A, Kopec G, Hryniewiecki T, Torbicki A, Mularek Kubzdela $T$, et al. Guidance for anticoagulation management in venous thromboembolism during the coronavirus disease 2019 (COVID-19) pandemic in Poland an expert opinion of the Section on Pulmonary Circulation of the Polish Cardiac Society. Kardiol Pol 2020; 78:642-6. [CrossRef]

4. Barnes $G$, Burnett $A$, Allen A, Blumenstein M, Clark NP, Cuker $A$, et al. Thromboembolism and anticoagulant therapy during the COVID-19 pandemic: interim clinical guidance from the anticoagulation forum. J Thromb Thrombolysis 2020; 50:72-81. [CrossRef]

5. Lazaridis D, Leung S, Kohler L, Smith $C H$, Kearson $M L$, Eraikhuemen $\mathrm{N}$. The impact of anticoagulation on COVID-19 (SARS CoV-2) patient outcomes: a systematic review. J Pharm Pract 2021; 8971900211015055. [CrossRef]

6. Patell R, Bogue T, Koshy A, Bindal P, Merrill M, Aird WC, et al. Postdischarge thrombosis and hemorrhage in patients with COVID-19. Blood 2020; 136:1342-6. [CrossRef]

7. National Institutes of Health. Coronavirus Disease 2019 (COVID-19) Treatment Guidelines. Available at: https://www.covid19treatmentguidelines.nih.gov. [accessed at 5.5.21].

8. Engelen MM, Vandenbriele C, Balthazar T, Claeys E, Gunst J, Guler I, et al. Incidence of venous thromboembolism in patients discharged after COVID-19 hospitalization. Semin Tromb Hemost 2021; 47:362-71. [CrossRef]

9. Fan BE, Umapathi T, Chua K, Chia YW, Wong SW, Tan $G W L$, et al. Delayed catastrophic thrombotic events in young and asymptomatic post COVID-19 patients. J Thromb Thrombolysis 2021; 51:971-7. [CrossRef]

10. Singh A, Patel Y, Zatakia J, Steiger D. Acute venous thromboembolism occuring many months following acute COVID-19. Am J Respir Crit Care Med 2021; 203:A3727. [CrossRef]

11. Becker RC. Anticipating the long-term cardiovascular effects of COVID-19. J Thromb Thrombolysis 2020; 50:512-24. [CrossRef]

12. Nalbandian A, Sehgal K, Gupta A, Madhavan MV, McGroder C, Stevens JS, et al. Post- acute COVID-19 syndrome. Nat Med 2021; 27:601-15. [CrossRef]

13. SeyedAlinaghi $S$, Afsahi AM, MohsseniPour M, Behnezhad F, Salehi MA, Barzegary A, et al. Late complicati- 
ons of COVID-19; a systematic review of current evidence. Arch Acad Emerg Med 2021; 9:e14. [CrossRef]

14. Marietta M, Ageno W, Artoni A, De Candia E, Gresele P, Marchetti M, et al. COVID-19 and haemostasis: a position paper from Italian Society on Thrombosis and Haemostasis (SISET). Blood Transfus 2020; 18:167-9. [CrossRef]

15. Moores LK, Tritschler T, Brosnahan S, Carrier M, Collen JF, Doerschug K, et al. Prevention, diagnosis and treatment of VTE in patients with coronavirus disease 2019: CHEST Guideline and Expert Panel Report. Chest 2020; 158:1 143-63. [CrossRef]
16. T.C. Sağlık Bakanlığı COVID-19 (SARS-CoV-2 Enfeksiyonu) Antisitokin- Antiinflamatuar Tedaviler, Koagulopati Yönetimi, 7 Kasım 2020, Ankara. Available at:

https://covid19.saglik.gov.tr/Eklenti/39296/0/covi d-19rehberiantisitokinantiinflamatuar tedavilerkoagulopatiyonetimipdf.pdf. Accessed at: 16.06.2021.

17. Zhou F, Yu T, Du R, Fan G, Liu Y, Liu Z, et al. Clinical course and risk factors for mortality of adult inpatients with COVID-19 in Wuhan, China: a retrospective cohort study. Lancet 2020; 395:105462. [CrossRef]

18. Cui S, Chen S, Li X, Liu S, Wang F. Prevalence of venous thromboembolism in patients with severe novel coronavirus pneumonia. J Thromb Haemost 2020; 18:1421-24. [CrossRef] 